\title{
The Forgotten and Twisted Conflict History of the Siam-Burma Death Railway
}

\author{
Sugumaran Narayanan
}

\begin{abstract}
The Siam-Burma Death Railway was a World War II Japanese project. Workers on the project were subjected to terrible conditions as Japan's primary goal was to complete the project in the shortest time in the most efficient manner. The majority of the forced labor was from Southeast Asia which included families and children, many of whom ended up becoming orphans at the conclusion of the war. While about 13,000 prisoners of war (POWs) from Europe, the U.S., and Australia died, hundreds of thousands of Southeast Asians perished (an exact number is unavailable). Western powers and experts from the West managed to document the hardship and details of the POWs. Even movies were made about them, among them the much-celebrated "Bridge on River Kwai." On the Southeast Asian side, however, little information is available, let alone online materials. Research is scarce. This project attempts to address this gap in the literature.
\end{abstract}

Index Terms-Forced labor, personal interview research, Southeast Asia, WWII Death Railway.

\section{INTRODUCTION}

There is an acute lack of information on the Asian forced labor of the WW II Siam-Burma Death Railway despite the fact that this was Imperial Japan's largest war project. While there is abundant literature on western POWs, literature on Asian workers are scarce in the field of History. There is none in Political Science. To illustrate this point, the literature provides exact numbers of POW death reported, that is, $25 \%$ of the total POW workforce. Additionally while there are detailed reports on how exactly the bodies of the POWs were managed after the war (exhumed and transferred to clearly-defined cemeteries), there is nothing to mark the graves of the dead Asians. This should be an undertaking of governments and academics but there appears to be a lack of interest. Hence, it is left to academics like us to initiate it as no institution has so far seen the importance of preserving this part of our history. If we do not document the oral histories of the few remaining survivors in their eighties and nineties (in Thailand, Malaysia, and India) the forgotten history will soon will be lost forever.

As a secondary question, my study investigates why nothing much had been done by governments to gather information on the torture, and seek compensation or otherwise. Because such a significant part of our history has

Manuscript received April 30, 2018; revised September 11, 2018. This work was supported in part by the Office of Sponsored Programs and Research, Midwestern State University, 3410 Taft Blvd., Wichita Falls, TX 76308, USA.

Sugumaran Narayanan is with Midwestern State University, 3410 Taft Blvd., Wichita Falls, TX 76308, USA. (e-mail: sugumaran.narayanan@mwsu.edu). been neglected, this project embarks on gathering information or access to persons with information on this forgotten history, sources with information for example archives and government leaders (for instance the Tourism Minister of Malaysia himself lost a family member in the Death Railway), interested organizations, agencies, and non-governmental organizations NGOs), followed by the careful documentation of the above.

In short, the project investigates; 1. What actually happened at the Death Railway site? (Historical question) 2. Why are the relevant governments reluctant to answer this question, (except when related to POWs), and sanction research into it? (Political question), that leads to hypothesis 1. Horrific torture and human rights violations happened that we can clearly label this the "Asian holocaust." Any reports that the workers were paid is false, and hypothesis 2 . Third world countries where Asian labor was taken from were too poor to demand and simply wanted to move on after the war and these governments received secret payments from Japan.

\section{LITERATURE REVIEW}

Japan's ambitious World War II Death Railway project led to forced relocation and the kidnapping of workers from Indonesia, Malaysia, Thailand, India, and Indo-China. The story of this Siam-Burma Death Railway constitutes an important aspect of the Pacific theatre of the Second World War; a milestone in world history. Of Imperial Japan's organization projects, the Siam-Burma railway posed the biggest challenge [1] page 223. Almost the entire literature is comprised of information obtained from the POW eye witnesses and Japanese documents. The documents are unreliable because aggressors' accounts are either one-sided or watered down. There is also information elicited from POW diaries. Reference [2] and [1] attest to the above claims. Additionally reference [3] invoked historian Brian Farrell's statement,

"... and more important here, most of these memories have been passed on by the Western prisoners of war, mainly Australian and British ... But there were others involved in this horror, other points of view to be heard. Many more Europeans and Asians than Europeans were forced to work themselves to death as slaves to build this supply line, but it has been difficult to hear their voice bearing witness ..." [3] foreword page.

Japan did register worker details when they left their points of origin but eventually records of workers on the railroad site are poor, probably because Japan destroyed them [1]. As a result reported death toll numbers can range from 80,000 to 225,000 , depending on which record is being considered. 
The 258-mile railroad was built in only a year therefore human labor must have been squeezed to the maximum [4]. Additionally, there are uncertain numbers on how many people actually died. Reference [5] stated that the Allies claimed that 270,000 laborers were taken to the site but the actual number could be close to 500,000. Reference [6] argued that the Death Railway site in Thailand has now become a tourist attraction where both tourists and the world at large have fallen oblivious to the sufferings of the workers. Additionally the horrors faced by the workers were under-reported. Even the much-celebrated award-winning movie "Bridge on the River Kwai" portrayed only the sufferings of the POWs. Not a single minute of the movie depicted images of Asian workers let alone their sufferings. So little have been compiled and reported that one of the few historians who worked on this project, Paul Kratoska titled his edited volume "Unknown Histories." A handful of historians compiled various reports from various sources (none from survivors). Reference [2] provided accounts of inhumane treatment by the Japanese soldiers. He stated that Japanese soldiers resorted to live burials of workers who suffered from cholera and other contagious diseases because the soldiers feared they would eventually contract these diseases from the workers. Many died of malnutrition or starvation [3] page 67. Some were even forced to dig their own graves [3] page 69. Some others on the other hand were either hanged or beheaded by Japanese soldiers, sometimes for the petty offense of possession of a small amount of sugar [3] page 70. Diseased workers were either thrown into flooded rivers or left to die in the open [3] page 94. Women were turned into sex slaves [3] page 55-56). Historians have reported that Asian workers clearly faced a worse fate than the European POWs [7] page 329.

A small percentage of the workers went to the railroad construction site voluntarily. In the very early stages of the construction of the railroad, the Japanese government promised lucrative allowances, gratuities, and leave to visit the home country but it never kept its promise [8] page 182-83 Reference [3] provided a rare witness testimony of one survivor, Tan Choon Keng, who stated that a promise of a first class rail ticket to Bangkok, Thailand ended up with a hundreds-of-mile congested ride on a goods truck that was normally used to transport cattle. While Tan Choon Keng was among the minority that relocated voluntarily, the majority were taken against their wishes. For instance, the Japanese would screen free movies and when the cinema was filled they would lock the doors, kidnap all the patrons and ship them to the railroad site. Additionally many were seized from homes, streets, stores, and parks [9] page 256.

In 1943, the puppet Thai prime minister declared,

" ... in this time of crisis, it's urgent ... use whatever means you can devise to levy as many Chinese as needed for construction of the military railroad ... to carry out forced recruitment of Chinese labour" [10] page 205.

While extant literature lacks sufficient data on the Asian labor, there is a hole in the literature on the question of why governments are not keen to take up or seriously analyze the issue. The European holocaust received well-deserved publicity and serious actions by numerous governments. Of the very limited literature on this, one scholar, Bruce
Reynolds pointed out political reasons but did not explain further. In defense of the POWs, the British government took steps to act against the Japanese after the war but none for the Asian workers even though the Asians were British subjects prior to Japanese invasion [7].

\section{Methodology}

Three countries, Thailand, Malaysia, and India (and in future, possibly, a fourth) are analyzed in this study. The study began with identifying survivors of the Death Railway. My preliminary research pointed out to approximately 50 survivors, collectively in Thailand, Malaysia, and India. I shortlisted 20 out of the 50 survivors to be interviewed. I started the project by conducting interviews and discussions with them. I also held discussions with children of survivors if survivors are dead or if they have serious memory issues. Accounts of the children were not as accurate as accounts from survivors themselves however in the course of their lives the children must have heard many stories from their parents about their experience. Next, discussions were planned to be held with former and current government leaders and discussions with Japanese ambassadors of the three countries. Additionally, discussions involving relevant non-governmental organizations (NGOs) in these countries were carried out. Some of these NGOs are interest groups sympathetic to the cause while others are think tanks and agencies. The project also involves visits to archives and museums. Some of the steps may overlap and done simultaneously and is not a layered or hierarchical design. While the discussions with survivors, NGOs, and visits to museums will elicit information about my first research question, discussions with leaders, ambassadors, and some NGOs will answer my second research question. A carefully worded questionnaire will be administered in order to collect the most data and only pertinent data. I have, in the past carried out two different field projects therefore I am equipped with ample experience to embark on this. The opinions and stories of the survivors (or their children) will be compared with those of the government leaders, ambassadors, and NGOs. The field work will provide me with the necessary data to carry out a thorough analysis of the two research questions posed upon return to the U.S. The visits to the Death Railway site in Thailand and the museums and archives in Thailand and India will enable me to understand more clearly what actually happened at the Death Railway. My analysis and conclusions will either support the theories already developed or dispute them. In any case my study will add to the limited literature on this subject. The questions posed to the survivor were:

1. For the record, can you state your name

2. For the record what is your date of birth and where were you born?

3. What was your primary occupation in the years before the war?

4. What was your immediate occupation before you were taken away?

5. Can you describe the circumstances surrounding the time when you were taken away, for e.g. who took 
you away, what did they say to you, was it a Japanese soldier or a Malayan agent etc?

6. Which town were you taken away from?

7. Where was your final destination? Was there a stopover?

8. What mode(s) of transportation was employed?

9. Were you taken alone or with others? Who were they?

10. Please describe the trip there

11. What were your duties at the camp?

12. On average, how many hours did you work on a typical day?

13. Did you get paid for your work? If yes, how much?

14. Were you allowed to spend the money paid to you? If yes, describe.

15. What kind of food were you served? Frequency?

16. Did you see/meet any POW? If yes, please provide some details

17. Were there medical facilities? What happened to workers who fell ill?

18. Did you witness deaths? Please describe

19. How would you describe the overall treatment of the Japanese towards you? How would you describe the overall treatment of the Japanese towards others?

20. Who supervised your work? Do you remember the names?

21. Were all supervisors Japanese? Can you remember names/ranks?

22. When did you return to Malaysia? Do you remember the date/month/year?

23. What mode of transportation for the return? Any stopovers?

24. How many people returned with you? Did you know them before the abduction or after arriving at the camp?

25. Please describe the trip back

26. Please describe your overall experience at the camp

27. Upon your return, how was the reception from your family members?

28. Did they notice any changes in you? If yes, how?

Additional questions: Do you have, in your possession, any photos, IDs, tags, documents, pay slips, or materials related to this? Can we please have them? If no, can we please make a copy of them?

The questions posed to the children or relatives of the victims were:

1. For the record, can you state your name

2. For the record what is your date of birth and where were you born?

3. What was your relationship to the survivor?

4. What was his/her name?

5. What was his/her date of birth and where was he/she born?

6. What was his/her primary occupation in the years before the war?
7. What was his/her immediate occupation before he/she was taken away?

8. Can you describe the circumstances surrounding the time when he/she was taken away, for e.g. who took him/her away, what did they say to him/her, was it a Japanese soldier or a Malayan agent etc?

9. From which town was he/she taken away from?

10. Where was his/her final destination? Was there a stopover?

11. What mode(s) of transportation was employed?

12. Was he/she taken alone or with others? Who were they?

13. Did he/she describe the trip there? If yes, please describe

14. What were his/her duties at the camp?

15. On average, how many hours did he/she work on a typical day?

16. Did he/she get paid for his/her work? If yes, how much?

17. Was he/she allowed to spend the money paid to him/her? If yes, describe.

18. What kind of food was he/she served? Frequency?

19. Did he/she see/meet any POW? If yes, please provide some details

20. Were there medical facilities? What happened to workers who fell ill?

21. Did he/she witness deaths? Please describe

22. How would you describe the overall treatment of the Japanese towards him/her? How would you describe the overall treatment of the Japanese towards others?

23. Who supervised his/her work? Did he/she mention names/ranks?

24. Were all supervisors Japanese?

25. When did he/she return to Malaysia? Do you remember the date/month/year?

26. What mode of transportation for the return? Any stopovers?

27. How many people returned with him/her? Did he/she know them before the abduction or after arriving at the camp?

28. Please describe the trip back

29. Please describe his/her overall experience at the camp

30. Upon his/her return, how was the reception from your family members?

31. Did you notice any changes in him/her? If yes, how?

Additional questions: Do you have, in your possession, any photos or materials related to this? Can we please have them? If no, can we please make a copy of them?

\section{RESULTS AND DISCUSSION}

The Table I below depicts a simplified quick guide to the answers received from the survivors for the most important questions posed to them:

TABLE I: BRIEF SUMMARY OF LIFE AND CONDITIONS AT THE DEATH RAILWAY

\begin{tabular}{|c|c|c|c|c|c|c|}
\hline Actor & $\begin{array}{c}\text { Hours } \\
\text { worked/day }\end{array}$ & Paid or not & Food & Medical facilities & $\begin{array}{c}\text { The conditions/Torture or } \\
\text { not }\end{array}$ & $\begin{array}{c}\text { Witnessed deaths?/ } \\
\text { Description of deaths }\end{array}$ \\
\hline $\begin{array}{c}\text { Child survivor } \\
\text { (woman) }\end{array}$ & Was a child & N/A & Bad & Uncertain & Yes/Gruesome \\
\hline $\begin{array}{c}\text { Male survivor } \\
1\end{array}$ & 12 or more & Yes, a little & $\begin{array}{c}\text { Very } \\
\text { bad }\end{array}$ & Very bad & Yes/Only POWs \\
\hline
\end{tabular}




\begin{tabular}{|c|c|c|c|c|c|c|}
\hline $\begin{array}{c}\text { Male survivor } \\
2\end{array}$ & 12 or more & $\begin{array}{c}\text { Yes, just a } \\
\text { little }\end{array}$ & Bad & Bad but available & Bad/Only POWs & Yes/Gruesome \\
\hline $\begin{array}{c}\text { Male external } \\
\text { interview 1 }\end{array}$ & 12 or more & N/A & $\begin{array}{c}\text { Very } \\
\text { bad }\end{array}$ & Bad but available & $\begin{array}{c}\text { Bad/Both POWs and Asians } \\
\text { but POWs worse }\end{array}$ & Yes/Can't remember \\
\hline $\begin{array}{c}\text { Male external } \\
\text { interview 2 }\end{array}$ & $\begin{array}{c}\text { Unable to recall } \\
\text { (N/A) }\end{array}$ & $\begin{array}{c}\text { Unable to } \\
\text { recall (N/A) }\end{array}$ & Bad & $\begin{array}{c}\text { Visiting doctor (not } \\
\text { frequent or regular) }\end{array}$ & $\begin{array}{c}\text { Yes but unable to recall } \\
\text { details }\end{array}$ & Yes/Can't remember \\
\hline
\end{tabular}

As shown in the table above, the interviews picked up some surprises. Extant literature suggested that the Asian laborers did not get paid for the work that they performed at the railway site. My interviewees however answered otherwise. Some of them mentioned that they were paid during their stay there while others said that they were paid at the end of their stay.

Another surprise account that the interviews found was that torture towards Asian workers were much lesser than the torture faced by the POWs who were almost completely western (U.S., British, Australian, and others) POWs. The answers to the questions clearly showed that western POWs were treated extremely harshly by Japanese soldiers. Asian laborers too faced hardship and some torture but not as terrible. One survivor said that the Asians were allowed to keep cigarettes but were strictly told not to share them with western POWs. One Asian worker who took pity on a POW and tried to hand him a cigarette was harshly kicked by a Japanese soldier. The child survivor, who is now in her $80 \mathrm{~s}$ mentioned that while life was bad, there were some good memories. For example she remembered that some Japanese soldiers used to joke with her and treated her as a child and not as an offspring of a prisoner. She was allowed to attend school and classes were not a terrible setting. She learned Japanese songs and to a certain extent enjoyed the life of a normal student. She was not particularly sure of any torture, be it the POWs or Asian workers.

On deaths, the answered matched the literature. All survivors including the child survivor witnessed deaths, mostly gruesome. One of them described terrible deaths of POWs and how they were murdered. Another described torture of the POWs followed by their deaths. Another described dead bodies found scattered all over after a bombing raid by American fighters. The child survivor still remembers scattered dead bodies after an American air raid.

The interviews, without doubt pointed to the fact that food served to the workers lacked quality and that the Japanese definitely did not care about the palatability of the food. Subjects complained about quality and that the food was at times too salty and at other times completely bland. It was surprising to find that while doctors were only intermittently available, medical facilities were not completely absent. Doctors were made available and made their rounds but on an infrequent basis. Some of these doctors were Southeast Asians themselves. The overall quality of medical care however was low.

Except for the child survivor all other interview subjects agreed that they have, or continue to have trauma from the experience. While one survivor was keen to revisit the majority of them declined a fully paid trip to revisit the site (which is now a tourist attraction). The reasons were inconclusive but points towards fear of trauma and health reasons.

Because of time and budget the second research question has been postponed to the next phase of the project (except for an interview that was conducted with the Chairman and officials of Death Railway Interest Group, or DRIG). DRIG provided some significant and interesting answers as to why governments have not been, and still not keen in revisiting or taking up the issue. Because these conclusions need to be compared with other parties; cabinet Ministers (the equivalent of cabinet Secretaries), NGO leaders, keepers of archives, ambassadors, and possibly heads of states and surviving members of WWII armed forces personnel, the DRIG explanations, for now cannot be generalized, and will be considered inconclusive.

\section{CONCLUSION}

This research uncovered some interesting points pertaining to life and conditions in the Siam-Burma Death Railway of WWII. While it matches certain aspects of the literature, the answers from interview subjects painted a fairly different picture with regards to the level of torture and who were actually tortured. Additionally the interviews received affirmative to the question on whether the Asian workers were paid or not. Because of time and budget, only a portion of those shortlisted were interviewed. This is a continuing project. Perhaps more details will be uncovered as more interviews are carried out.

To elicit answers for the second research question, interviews will be held with the parties mentioned above in the near future.

\section{REFERENCES}

[1] H. Hovinga, "End of a forgotten drama: The reception and repatriation of romusha after the Japanese capitulation," in Asian Labor in the Wartime Japanese Empire: Unknown Histories, P. Kratoska, Ed. New York: M.E. Sharpe, 2005.

[2] D. Boggette, "The silenced voices of history: Asian workers on the death railway," Third World Resurgence Archives, no. 278, pp. 44-47, 2013.

[3] C. B. Goh, Living Hell: Story of a WWII Survivor at the Death Railway, Singapore: ASIAPAC, 1999.

[4] The Telegraph. (2016). Inside Burma's death railway museum. [Online]. Available: http://www.telegraph.co.uk/travel/destinations/asia/myanmar/articles/ Inside-Burmas-Death-Railway-museum/

[5] D. Boggette, "Cast into Oblivion: Malayan Tamils of the death railway," FMT News Letters, 2015.

[6] P. Karmugilan. (2016). Death railway: The horror lives on. The Malaysian Times. [Online]. Available: http://www.themalaysiantimes.com.my/death-railway-the-horror-lives -on/

[7] B. Reynolds, "History, memory, compensation, and reconciliation: The abuse of labor along the Thailand-Burma railway," in Asian Labor in the Wartime Japanese Empire: Unknown Histories, P. Kratoska, Ed. New York: M.E. Sharpe, 2005.

[8] P. Kratoska, The Japanese Occupation of Malaya: A Social and Economic History, Honolulu: University of Hawaii Press, 1997.

[9] N. Michiko, "Malayan labor on the Thailand-Burma railway," in Asian Labor in the Wartime Japanese Empire: Unknown Histories, P. Kratoska, Ed. New York: M.E. Sharpe, 2005. 
[10] E. Murashima, "The Thai-Japanese alliance and the Chinese of Thailand," in Southeast Asian Minorities in the Wartime Japanese Empire, P. Kratoska, Ed. New York: RoutledgeCurzon, 2002.

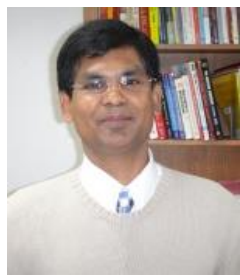

Sugumaran Narayanan is a political science professor at Midwestern State University, Texas, USA. He has been with this institution for about 10 years now. He obtained his Ph.D. from the University of Alabama in 2008 with a major in international politics and a minor in American politics. While his areas of expertise are international politics and civil conflicts, he has a keen interest in US presidential politics. Dr Narayanan has carried out both quantitative and qualitative scholarly work. Recently he carried out field work pertaining to civil wars in Southeast Asia as well as visits to peaceful native communities. In doing so he compares the correlates of war with peace. In his civil war field work research he held discussions with interesting personalities; rebel leaders, heads of governments (for example former prime minister Dr Mahathir Mohamad and former president Noynoy Aquino), former first lady Imeda Marcos, mediators of peace talks etc. Prior to joining higher education he has worked in public multinational organizations.
Dr. Narayanan has been bestowed with various awards and recognitions. He has presented in numerous conferences, acted as chair/facilitator of sessions, and delivered keynote addresses and invited talks.

During president Obama's first term, he participated in invited roundtable discussion along with about 50 persons worldwide to discuss human rights conditions in various countries in U.S. State Department's "Roundtable over Human Rights", chaired by State Department Assistant Secretary Michael Posner. Additionally, also during the Obama first term, he was invited to judge/rate important federal government contests, nominate community exemplary figures for Presidential medals of honor, and participated in invited White House conference calls and policy meetings.

Dr. Narayanan is also a board member, Malaysian-American Foundation. 